\title{
The Ecuadorian Amazon: A Data Analysis of Social and Educational Characteristics of the Population
}

\author{
Gina Valdivieso ${ }^{1}$, Efstathios Stefos ${ }^{2} \&$ Ruth Lalama $^{3}$ \\ ${ }^{1}$ Faculty of Psychology, Pontifical Catholic University of Ecuador, Quito, Ecuador \\ ${ }^{2}$ National University of Education (UNAE), Azogues, Ecuador \\ ${ }^{3}$ Independent Consultant Psychologist and Educational Psychologist, Quito, Ecuador \\ Correspondence: Efstathios Stefos, National University of Education (UNAE), Azogues, Cañar, Parroquia Javier \\ Loyola (sector Chuquipata), Ecuador. Tel: 593-7-370-1200. E-mail: estefos@aegean.gr
}

Received: October 9, 2016

Accepted: October 17, $2016 \quad$ Online Published: January 5, 2017

doi:10.5539/res.v9n1p120

URL: http://dx.doi.org/10.5539/res.v9n1p120

\begin{abstract}
The present study describes the social and educational characteristics of the Ecuadorian Amazon population. For this purpose, the data obtained from the National Survey of Employment, Unemployment and Underemployment of 2014 was used in this research. A descriptive statistical analysis presents the frequency, the percentages and the graphs of the variables related to the area in which people live, gender, age, ethnic self-identification, language spoken, marital status and level of instruction. Other variables are the use of computer and internet, place of birth, reason why they live in the Amazon region, type of activity or inactivity, how do they feel in their jobs, and groups of occupation. Also, a factorial analysis was used to show the main and most important criteria of differentiation and the the clusters of people with similar characteristics.
\end{abstract}

Keywords: Ecuadorian Amazon, social and educational characteristics, data analysis

\section{Introduction}

Ecuador, Latin-American country, in South America, has four natural regions: Coast, Andean region, insular region and Amazon region. The Amazon region corresponds to the $45 \%$ of the Ecuadorian territory but according to the Census of 2010 its population corresponds to $5.11 \%$ of the total population of the country (INEC, 2010; Matamoros, 2007).

The Amazon region is geographically divided into two subregions, the highlands and the lowlands, extends from the mountain range of Andes into the basin of Amazon and includes unspoiled pristine lands, cloud forests of the Andes and tropical rainforests of the lowlands. The Ecuadorian Amazon is still an extremely biodiverse region in spite of environmental degradation linked to oil development.

The indigenous populations of Amazon region maintain their traditional life and some of them remain isolated deep in the Amazon forests. The climate is humid and very warm with frequent heavy rains especially in the lower elevations.

The interest in describing the social and educational characteristics of the Ecuadorian Amazon population, in terms of kind of activity and well-being, as well as the educational instruction, is due to the importance of the region in the social and economic development of Ecuador.

The results of this analysis will describe the profile of people living in Ecuadorian Amazon and enable the possibility to design plans for the improvement of their life (Stefos et al., 2016).

\section{Methodology}

This research makes a description of the characteristics of a sample of 22843 people of the population of the Amazon region who participated in the National Survey of Employment, Unemployment and Underemployment (INEC, 2014).

A descriptive analysis and a statistical multidimensional analysis were realized in order to present the frequencies and percentages of the variables related with the social and educational characteristics, the 
differentiation criteria and the groups with similar characteristics of people living in the Ecuadorian Amazon region (Athanasiadis, 1995).

The Multiple Correspondence Analysis was used to find how the people that participated in the survey are differentiated according to their answers (Stefos, 2015). This method describes the simultaneous correlation of the variables used in the survey. The axes of the Factor Analysis are the differentiation criteria which express oppositions in the given answers by the respondents (Stefos \& Papapostolou, 2013).

The Hierarchical Analysis classifies the respondents according to their answers and common characteristics. This method also presents a classification figure that connects the groups and a figure of the correspondence analysis that shows the centroids of the groups in both axes (Kalouri et al., 2011).

The Faculty of Humanities of the University of the Aegean offered the statistical software SPAD v.4.5 that was used to analyze the results of the study.

\section{Results of the Descriptive Analysis}

$38.08 \%$ of the people who participated in the survey live in urban area, while the $61.92 \%$ live in rural area (Table $1)$.

Table 1. Area

\begin{tabular}{ccc}
\hline & $\mathrm{n}$ & $\%$ \\
\hline Urban & 8699 & $38.08 \%$ \\
Rural & 14144 & $61.92 \%$ \\
Total & 22843 & $100.00 \%$ \\
\hline
\end{tabular}

In terms of gender, $50.47 \%$ are men and $49.53 \%$ are women (Table 2).

Table 2. Gender

\begin{tabular}{ccc}
\hline & $\mathrm{n}$ & $\%$ \\
\hline Men & 11530 & $50.47 \%$ \\
Women & 11313 & $49.53 \%$ \\
Total & 22843 & $100.00 \%$ \\
\hline
\end{tabular}

$23.89 \%$ are children under age $10,24.48 \%$ are young people between the ages $10-19,14.57 \%$ are persons between the ages $20-29,12.77 \%$ are persons between the ages $30-39,9.74 \%$ are persons between the ages $40-49,6.94 \%$ are people between the ages $50-59,4.29 \%$ are people between the ages $60-69,2.29 \%$ are people between the ages $70-79,0.89 \%$ are people between the ages $80-89$ and $0.14 \%$ are 90 or more years old (Table 3 ).

Table 3. Age

\begin{tabular}{ccc}
\hline & $\mathrm{n}$ & $\%$ \\
\hline$[0,10)$ & 5458 & $23.89 \%$ \\
{$[10,20)$} & 5592 & $24.48 \%$ \\
{$[20,30)$} & 3328 & $14.57 \%$ \\
{$[30,40)$} & 2916 & $12.77 \%$ \\
{$[40,50)$} & 2224 & $9.74 \%$ \\
{$[50,60)$} & 1585 & $6.94 \%$ \\
{$[60,70)$} & 981 & $4.29 \%$ \\
{$[70,80)$} & 522 & $2.29 \%$ \\
{$[80,90)$} & 203 & $0.89 \%$ \\
90 and older & 33 & $0.14 \%$ \\
\hline
\end{tabular}




\begin{tabular}{ccc}
\hline N/A & 1 & $0.004 \%$ \\
Total & 22843 & $100.00 \%$
\end{tabular}

$26.86 \%$ of persons participated in the investigation are indigenous, $1.04 \%$ are afro-ecuadorians, $0.80 \%$ are blacks, $0.66 \%$ are mulattos, $0.21 \%$ are montubios, $57.99 \%$ are mestizos y, $1.01 \%$ are whites (Table 4 ).

Table 4. Ethnic self-identification

\begin{tabular}{ccc}
\hline & $\mathrm{n}$ & $\%$ \\
\hline Indigenous & 6136 & $26.86 \%$ \\
Afro-ecuadorian & 237 & $1.04 \%$ \\
Black & 182 & $0.80 \%$ \\
Mulatto & 150 & $0.66 \%$ \\
Montubio & 49 & $0.21 \%$ \\
Mestizo & 13247 & $57.99 \%$ \\
White & 231 & $1.01 \%$ \\
Other & 11 & $0.05 \%$ \\
N/A & 2600 & $11.38 \%$ \\
Total & 22843 & $100.00 \%$ \\
\hline
\end{tabular}

$0.71 \%$ speak only indigenous language, $21.85 \%$ speak indigenous language and Spanish, $65.58 \%$ speak only Spanish, $0.28 \%$ speak Spanish and foreign language, $0.01 \%$ speak indigenous and foreign language, $0.08 \%$ speak only foreign language y $0.11 \%$ do not speak (Table 5).

Table 5. Spoken language

\begin{tabular}{ccc}
\hline & $\mathrm{n}$ & $\%$ \\
\hline Only indigenous language & 163 & $0.71 \%$ \\
Speak indigenous language and Spanish & 4.992 & $21.85 \%$ \\
Only Spanish & 14980 & $65.58 \%$ \\
Spanish and foreign language & 64 & $0.28 \%$ \\
Indigenous and foreign language & 2 & $0.01 \%$ \\
Only foreign language & 18 & $0.08 \%$ \\
Does not speak & 24 & $0.11 \%$ \\
N/A & 2600 & $11.38 \%$ \\
Total & 22843 & $100.00 \%$ \\
\hline
\end{tabular}

$22.18 \%$ are married, $2.28 \%$ are separated, $1.11 \%$ are divorced, $2.06 \%$ are widowed, $14.88 \%$ in a common law relationship and $28.24 \%$ are single (Table 6 ).

Table 6. Marital status

\begin{tabular}{ccc}
\hline & $\mathrm{n}$ & $\%$ \\
\hline Married & 5067 & $22.18 \%$ \\
Separated & 520 & $2.28 \%$ \\
Divorced & 253 & $1.11 \%$ \\
\hline
\end{tabular}




\begin{tabular}{ccc}
\hline Widowed & 471 & $2.06 \%$ \\
Common law relationship & 3399 & $14.88 \%$ \\
Single & 6452 & $28.24 \%$ \\
N/A & 6681 & $29.25 \%$ \\
Total & 22843 & $100.00 \%$ \\
\hline
\end{tabular}

$2.88 \%$ of people that participated in the survey did not attended school, $0.39 \%$ attended literacy center, $19.65 \%$ has attended Primary education, $32.51 \%$ attended Basic education, $16.68 \%$ attended Secondary education, $8.70 \%$ attended Middle education, $1.06 \%$ Cycle Post-Baccalaureate, $6.41 \%$ Higher education and $0.35 \%$ attended a Postgraduate studies program (Table 7).

Table 7. Instruction level

\begin{tabular}{ccc}
\hline & $\mathrm{n}$ & $\%$ \\
\hline None & 657 & $2.88 \%$ \\
Literacy center & 88 & $0.39 \%$ \\
Primary education & 4489 & $19.65 \%$ \\
Basic education & 7426 & $32.51 \%$ \\
Secondary education & 3810 & $16.68 \%$ \\
Middle education & 1988 & $8.70 \%$ \\
Cycle Post-Baccalaureate & 242 & $1.06 \%$ \\
Higher education & 1464 & $6.41 \%$ \\
Postgraduate studies & 79 & $0.35 \%$ \\
N/A & 2600 & $11.38 \%$ \\
Total & 22843 & $100.00 \%$ \\
\hline
\end{tabular}

42.15\% have used computer and $39.00 \%$ internet during the last twelve months (Table 8 , Table 9).

Table 8. Use of computer during the last twelve months

\begin{tabular}{ccc}
\hline & $\mathrm{n}$ & $\%$ \\
\hline Yes & 9628 & $42.15 \%$ \\
No & 10553 & $46.20 \%$ \\
N/A & 2662 & $11.65 \%$ \\
Total & 22843 & $100.00 \%$ \\
\hline
\end{tabular}

Table 9. Use of internet during the last twelve months

\begin{tabular}{ccc}
\hline & $\mathrm{n}$ & $\%$ \\
\hline Yes & 8908 & $39.00 \%$ \\
No & 11273 & $49.35 \%$ \\
N/A & 2662 & $11.65 \%$ \\
Total & 22843 & $100.00 \%$ \\
\hline
\end{tabular}

$61.71 \%$ were born in the same city they live now, $36.31 \%$ were born in another part of the country and $1.97 \%$ were born in another country (Table 10). 
Table 10. Place of birth

\begin{tabular}{ccc}
\hline & $\mathrm{n}$ & $\%$ \\
\hline In the same city & 14097 & $61.71 \%$ \\
Another part of the country & 8295 & $36.31 \%$ \\
Another country & 451 & $1.97 \%$ \\
Total & 22843 & $100.00 \%$ \\
\hline
\end{tabular}

$10.94 \%$ moved to the Amazon region for job reasons, $1.56 \%$ to increase economic income, $2.81 \%$ for marriage, $0.59 \%$ for education, $0.32 \%$ for health or illness, $0.71 \%$ because they purchased a house or land or it was given to them, and $15.89 \%$ moved with their family (Table 11).

Table 11. Reasons to be living in the Amazon region

\begin{tabular}{ccc}
\hline & $\mathrm{n}$ & $\%$ \\
\hline Job & 2500 & $10.94 \%$ \\
Marriage & 356 & $1.56 \%$ \\
Education & 643 & $2.81 \%$ \\
Health or illness & 135 & $0.59 \%$ \\
Purchased or received a house or land & 72 & $0.32 \%$ \\
Moved with family & 163 & $0.71 \%$ \\
Other & 3630 & $15.89 \%$ \\
N/A & 164 & $0.72 \%$ \\
Total & 15180 & $66.45 \%$ \\
\hline
\end{tabular}

13303 of the respondents do not work: 8519 (37.29\%) because they are under 15, $273(1.20 \%)$ are open unemployed, $101(0.44 \%)$ are hidden unemployed and $4210(18.43 \%)$ are economically inactive (Table 12$)$.

Table 12. Type of activity

\begin{tabular}{ccc}
\hline & $\mathrm{n}$ & $\%$ \\
\hline Under 15 & 8519 & $37.29 \%$ \\
Employed & 3951 & $17.30 \%$ \\
Sub employed due to insufficiency of time & 988 & $4.33 \%$ \\
Sub employed due to low income & 277 & $1.21 \%$ \\
Other unsuitable job & 2862 & $12.53 \%$ \\
Job with no profit & 1655 & $7.25 \%$ \\
Job not classified & 7 & $0.03 \%$ \\
Open unemployment & 273 & $1.20 \%$ \\
Hidden unemployment & 101 & $0.44 \%$ \\
Economically inactive & 4210 & $18.43 \%$ \\
Total & 22843 & $100.00 \%$ \\
\hline
\end{tabular}

$0.32 \%$ are landlords, $0.62 \%$ are pensioners, $30.57 \%$ are students, $8.09 \%$ are housewives and $1.65 \%$ have some type of disability or handicap (Table 13). 
Table 13. Type of inactivity

\begin{tabular}{ccc}
\hline & $\mathrm{n}$ & $\%$ \\
\hline Landlord & 72 & $0.32 \%$ \\
Pensioners & 141 & $0.62 \%$ \\
Student & 6984 & $30.57 \%$ \\
Housewife & 1847 & $8.09 \%$ \\
Handicap & 378 & $1.65 \%$ \\
Other & 283 & $1.24 \%$ \\
N/A & 13138 & $57.51 \%$ \\
Total & 22843 & $100.00 \%$ \\
\hline
\end{tabular}

$28.24 \%$ are happy with their jobs, $8.11 \%$ are not quite happy, $5.07 \%$ are unhappy but satisfied and $1.10 \%$ are totally unhappy (Table 14).

Table 14. How do you feel about your job?

\begin{tabular}{ccc}
\hline & $\mathrm{n}$ & $\%$ \\
\hline Happy & 6450 & $28.24 \%$ \\
Not quite happy & 1853 & $8.11 \%$ \\
Unhappy but satisfied & 1157 & $5.07 \%$ \\
Totally unhappy & 251 & $1.10 \%$ \\
Does not know, does not respond & 29 & $0.13 \%$ \\
N/A & 13103 & $57.36 \%$ \\
Total & 22843 & $100.00 \%$ \\
\hline
\end{tabular}

$18.56 \%$ work in agriculture, ranching, hunting, forestry and fishing $1.55 \%$ work in the exploitation of mines and quarry, $1.78 \%$ in manufacture industries, $0.14 \%$ in electric, gas and air conditioning supplies, $0.12 \%$ in water and sewage system distribution, $2.88 \%$ in construction, $4.53 \%$ in trade business and automobile reparation, $1.62 \%$ in transportation and storage, $1.87 \%$ in lodging and food services, $0.36 \%$ in information and communication, $0.38 \%$ in professional and scientific activities, $0.63 \%$ in administrative and support services, $3.19 \%$ in defense, social security and public administration, and $2.37 \%$ in teaching (Table 15 ).

Table 15. Type of activity

\begin{tabular}{ccc}
\hline & $\mathrm{n}$ & $\%$ \\
\hline Agriculture, ranching, hunting, forestry and fishing & 4240 & $18.56 \%$ \\
Exploitation of mines and quarry & 354 & $1.55 \%$ \\
Manufacture industries & 407 & $1.78 \%$ \\
Electric, gas and air conditioning supplies & 32 & $0.14 \%$ \\
Water and sewage system distribution & 28 & $0.12 \%$ \\
Construction & 659 & $2.88 \%$ \\
Trade business and automobile reparation & 1035 & $4.53 \%$ \\
Storage and transportation & 371 & $1.62 \%$ \\
Food services and lodging & 427 & $1.87 \%$ \\
Information y communication & 83 & $0.36 \%$ \\
\hline
\end{tabular}




\begin{tabular}{ccc}
\hline Insurance and financial activities & 41 & $0.18 \%$ \\
Real estate & 3 & $0.01 \%$ \\
Professional and scientific activities & 87 & $0.38 \%$ \\
Administrative and support services & 144 & $0.63 \%$ \\
Public administration, defense and social security & 729 & $3.19 \%$ \\
Teaching & 541 & $2.37 \%$ \\
Health and social services & 205 & $0.90 \%$ \\
Arts, recreation and entertainment & 51 & $0.22 \%$ \\
Other service activities & 158 & $0.69 \%$ \\
Domestic service in private homes & 142 & $0.62 \%$ \\
Extraterritorial organizations & 3 & $0.01 \%$ \\
N/A & 13103 & $57.36 \%$ \\
Total & 22843 & $100.00 \%$ \\
\hline
\end{tabular}

$0.35 \%$ are managers and directors in the public system, $3.37 \%$ are scientists and intellectuals, $1.19 \%$ are graduate technicians and professionals, $1.62 \%$ are office employees, $6.92 \%$ are service workers and traders, $11.46 \%$ are qualified fishermen and farmers, $3.94 \%$ are operators and artisans, $3.07 \%$ are installation operators, machinery and assemble operators, $10.55 \%$ are not qualified workers or work in simple occupations and $0.18 \%$ work in armed forces (Table 16).

Table 16. Groups of occupation

\begin{tabular}{ccc}
\hline & $\mathrm{n}$ & $\%$ \\
\hline Managers and directors in the public system & 79 & $0.35 \%$ \\
Scientists and intellectuals profesionales científicos e intelectuales & 770 & $3.37 \%$ \\
Graduate technicians and professionals & 271 & $1.19 \%$ \\
Office employees & 369 & $1.62 \%$ \\
Service workers and traders & 1581 & $6.92 \%$ \\
Qualified fishermen and farmers & 2617 & $11.46 \%$ \\
Operators and artisans & 901 & $3.94 \%$ \\
Installation operators, machinery and assembly operators & 701 & $3.07 \%$ \\
Not qualified workers or work in simple occupations & 2411 & $10.55 \%$ \\
Armed forces & 40 & $0.18 \%$ \\
N/A & 13103 & $57.36 \%$ \\
\hline
\end{tabular}

\section{Results of Multiple Correspondence Analysis}

The characteristics related with the main differences among the 22843 people that participated in the survey are defined by the following criteria of differentiation:

\subsection{First Criterion of Differentiation-First Factor Axis, Inertia Percentage 14.83\%}

The first criterion of differentiation is consisted on one hand of children under 10 who live in rural area in the same place they were born. On the other hand, there are people that were born in another part of the country, they are happy with their jobs, married, they are mestizos and speak only Spanish. 


\subsection{Second Differentiation Criterion-Second Factor Axis, Inertia Percentage 9.14\%}

The second criterion of differentiation is consisted on one hand of students of Basic education that have always lived in the same place, have used computer and internet during the last twelve months and speak Spanish and indigenous language. On the other hand, there are people that were born in another part of the country, their instruction level is Primary education and went to live in the Amazon region for job reasons.

\subsection{Third Differentiation Criterion-Third Factor Axis, Inertia Percentage 6.47\%}

The third criterion of differentiation is consisted on one hand of people that live in urban area, have used computer and internet during the last twelve months, speak only Spanish, are mestizos, and their instruction level is Higher Education. On the other hand, there are qualified and not qualified workers that are indigenous, work in agriculture, ranching, hunting, foresting and fishing, speak indigenous language and Spanish and live in rural area (Stefos et al., 2011; Morineau, 1984).

\section{Results of the Hierarchical Analysis}

The hierarchical clustering led to the formation of five groups which are graphically represented in Figure 1.

1) First group (2600 persons, $11.38 \%$ of the sample)

The first group consists of children under 10 years old who live in rural area in the same place they were born.

2) Second group (2696 persons, $11.80 \%$ of the sample)

The second group consists of housewives who were born in another part of the country, have not used computer during the last 12 months and their instruction level is Primary education.

3) Third group ( 7712 persons, $33.76 \%$ of the sample)

The third group consists of young students of Basic education, who have always lived in the same place, have used computer and internet during the last twelve months and speak Spanish and indigenous language.

4) Fourth group (4663 persons, $20.41 \%$ of the sample)

The fourth group consists of qualified and not qualified employees that work in agriculture, ranching, hunting, foresting and fishing, their instruction level is Primary education, feel happy in their jobs and speak Spanish and indigenous language.

5) Fifth group (5172 persons, $22.64 \%$ of the sample)

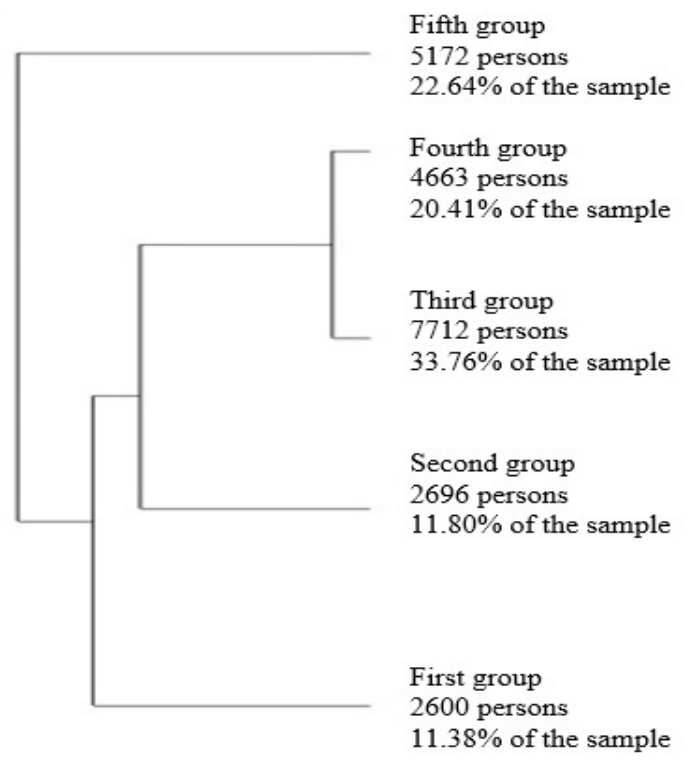

Figure 1. Hierarchical analysis 
The fifth group consists of service workers, traders, scientists and intellectuals that feel happy with their jobs, their instruction level is Higher and Secondary education, live in urban area, are mestizos and speak only Spanish.

The differences between the groups are shown in Figure 2, where the multiple correspondence analysis (factorial level $1 \times 2$ ) present the centroids of the five groups in both axes. It also defines the differences and similarities among the people of the five groups (Martin, 2008).

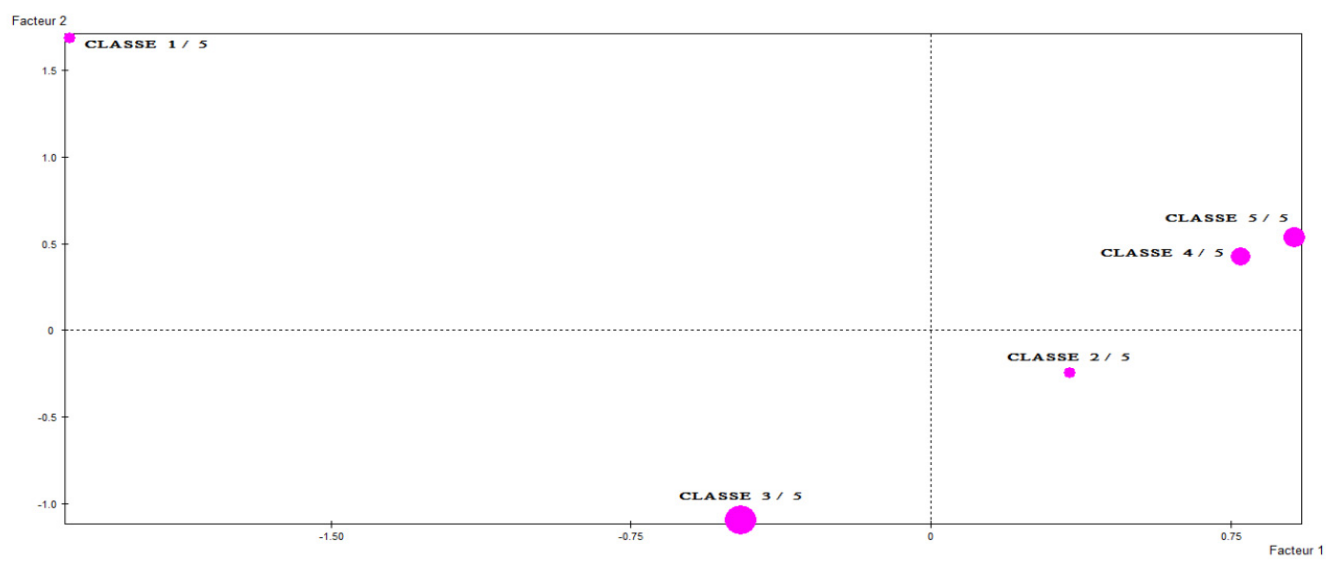

Figure 2. Correspondence analysis

\section{Conclusions}

The data analysis shows that $48.37 \%$ of the people that participated in the survey are young people under the age of $20.26 .86 \%$ of the population are indigenous and $57.99 \%$ mestizos.

Only $0.37 \%$ of the people speak a foreign language. $2.88 \%$ of the respondents have no education and $6.76 \%$ have University studies (Sarmiento et al., 2016).

$36.31 \%$ were born in another part of the country and for different reasons have moved to the Amazon region. $15.89 \%$ went to Amazon region for family reasons and $10.94 \%$ for job reasons.

Additionally, the information shows that only $1.10 \%$ of the people feel totally unhappy with their jobs. The highest percentage in the occupation item works in agriculture, ranching, hunting, foresting and fishing (18.56\%).

The factorial analysis confirmed the above mentioned results. $11.38 \%$ of the sample are children under the age of 10. $20.41 \%$ are qualified and not qualified workers that work in agriculture, ranching, hunting, foresting and fishing, while $22.64 \%$ are service workers, traders, scientists and intellectuals (Stefos et al., 2005).

\section{Acknowledgements}

We want to express our deep gratitude to the Faculty of Humanities of the University of the Aegean that offered the software SPAD v. 4.5 we used in this study.

\section{References}

Athanasiadis, I. (1995). Correspondence Analysis and Hierarchical Classification. In New Technologies Editions (pp. 51-56).

Benzecri, P. (1992). Correspondence Analysis Handbook. New York: Dekker.

Kalouri, R., Athanasiadis, I., \& Stefos, E. (2011). The social background of the students of the Greek Technological Educational Institutions. In The Proceedings of the International Scientific Conference eRA-6 (pp. 32-40). Piraeus.

Kampouropoulou, M., Fokiali, P., Efstathiou, I., Koutris, T., \& Stefos, E. (2015). Students' Views on the Use of a Virtual Educational Museum. Review of European Studies, 7(11), 1-6. https://dx.doi.org/10.5539/res.v7n11p1

Martin, O. (2008). The analysis of quantitative data (pp. 86-88). Athens: Topos. 
Matamoros, A. (2007). Document about management of Amazonian biodiversity in Ecuador (p. 118). Amazon Cooperation Treaty Organization-OTCA. Program OTCA-BID ATN/OC-9251-RG.

Morineau, A. (1984). Note sur la Caracterisation Statistique d'une Classe et les Valeurs-tests. Bulletin Technique du Centre de Statistique et d'Informatique Appliquées, 2(1-2), 20-27.

National Institute of Statistics and Census of Ecuador-INEC. (2014). National Survey of Employment, Unemployment and Underemployment-ENEMDU. Quito, Ecuador.

National Institute of Statistics and Census of Ecuador-INEC. (2010). Census of Ecuador. Quito, Ecuador.

Sarmiento, N. M., Paredes, P. A. M., \& Stefos, E. (2016). Deaths by Suicide in Ecuador: A Quantitative Data Analysis. Review of European Studies, 8(1), 145-156. https://dx.doi.org/10.5539/res.v8n1p145

Stefos, E., \& Papapostolou, I. (2013). Research Methodology. Processes and suggestions (p. 406). Rhodes: Evdimos Editions.

Stefos, E. (2015). Causes of Death of Indigenous Ecuadorians. International Journal of Clinical Medicine Research, 2(6), 65-70.

Stefos, E., Athanasiadis, I., Gialamas, B., \& Tsolakidis, C. (2011). The Use of New Technologies and the Project Method in Teaching Statistics: A Case Study in Higher Education. HMS i JME, 3, 84-100.

Stefos, E., Benalcázar, J. M. E., Coral, C. M. M., Córdova, V. P. A., Landázuri, M. M. B., Lombeida, S. E. S., ... Yajamín, V. R. X. (2016). A Data Analysis of Social and Educational Characteristics of Ecuadorians Aged 25-64. AASCIT Communications, 3(3), 184-189.

Stefos, E., Trantas, P., \& Athanasiadis, I. (2005). The distribution of the educational levels in the Prefectures of Greece according to Census 2001. In The Proceedings of the 18th Panhellenic Conference of Statistics (pp. 351-356). Rhodes.

\section{Copyrights}

Copyright for this article is retained by the author(s), with first publication rights granted to the journal.

This is an open-access article distributed under the terms and conditions of the Creative Commons Attribution license (http://creativecommons.org/licenses/by/4.0/). 